\title{
Pengaruh Gaya Kepemimpinan Terhadap Motivasi Kerja Karyawan Pada PT. Matahari Departement Store di MegaMall, Manado
}

\author{
Wulan Qimberly Wowor \\ Sontje M. Sumayku \\ Sofia A.P. Sambul \\ Jurusan Ilmu Administrasi, Program Studi Administrasi Bisnis \\ Faklutas Ilmu Sosial dan Politik, Universitas Sam Ratulangi Manado \\ wulan.wowor@yahoo.com
}

\begin{abstract}
This study aims to determine the Effect of Leadership Style on Employee Motivation at PT. Matahari Department Store at Mega Mall Manado. The research method used in this research is quantitative associative and data collection carried out by survey. The population in this research is all employees who work at Matahari Mega Mall. The sample determined in this study was using Slovin formula as many as 44 respondents using Correlation Analysis, $t$ Test, and Simple Linear Regression. The results of $R$ show 0.370 means that the relationship between Work Leadership and Motivation Style is Quite Strong, $R$ Square shows 0,137 which means Work Motivation Variables are influenced by 13, 70\% by Leadership Style Variables and the remaining $86.30 \%$ are influenced by other variables not used in this study. The t test shows a significant value of 0.013, which means that the Leadership Style Variable has a Positive and Significant effect on the Employee Motivation Variables. The Simple Linear Regression equation obtained is $\boldsymbol{Y}=\mathbf{2 5 , 5 2 1}+\mathbf{0 , 6 0 7 . X 1}$. From these equations, the Constants show that if the Leadership Style is worth Zero, then Work Motivation is equal to 25,521. The Coefficient of Leadership Style is 0.607, meaning that if the other variables are fixed and the Leadership Style increases by 1 point or 1\%, Work Motivation will increase by 0.607 per one point / unit. From the results above it can be concluded that the leadership style has a positive influence on Employee Work Motivation, it is expected that the company maintains and improves the factors that influence Employee Work Motivation.
\end{abstract}

Keywords: Leadership Style, Motivation of Employee Work

Pendahuluan

Gaya Kepemimpinan yang efektif sangat dipengaruhi oleh kepribadian pemimpin. Setiap pemimpin perlu memiliki aspek-aspek kepribadian yang dapat menunjang usahanya dalam mewujudkan hubungan manusia yang efektif dengan anggota organisasinya. Gaya kepemimpinan (leadership) adalah proses mempengaruhi atau memberi contoh kepada pengikut-pengikutnya melalui proses komunikasi dalam upaya mencapai tujuan organisasi.

PT. Matahari Department Store adalah sebuah perusahaan ritel di Indonesia yang merupakan pemilik dari jaringan toserba Matahari. Saat ini, Matahari Department Store merupakan salah satu anak perusahaan dari Lippo Group. Per kuartal pertama tahun 2017, Matahari Department Store sudah mempunyai 151 gerai di lebih dari 60 kota di Indonesia dan satu gerai 
online mataharistore.com. Penerapan Gaya Kepemimpinan sangatlah berpengaruh terhadap motivasi kerja karyawan, karena di dalam motivasi kerja karyawan untuk memenuhi kebutuhannya sangat membutuhkan dukungan dari seorang pimpinan, karena itu setiap pemimpin harus mengetahui secara jelas tentang apa yang dibutuhkan oleh karyawan dan perusahaan agar mereka bias bekerja sama secara efektif.

Berdasarkan permasalahan tersebut bahwa kurangnya motivasi kerja pada karyawan tersebut sehingga diperlukan ketegasan dari pimpinan terhadap karyawan agar karyawan mempunyai motivasi yang tinggi dan loyal terhadap perusahaan. Untuk mencapai hal tersebut maka perlu didukung oleh Gaya Kepemimpinan yang sesuai dengan harapan karyawan sehingga karyawan merasa kebutuhannya terpenuhi. Sehingga mampu meningkat motivasi kerja karyawan.

Penerapan Gaya Kepemimpinan sangatlah berpengaruh terhadap motivasi kerja karyawan, karena di dalam motivasi kerja karyawan untuk memenuhi kebutuhannya sangat membutuhkan dukungan dari seorang pimpinan, karena itu setiap pemimpin harus mengetahui secara jelas tentang apa yang dibutuhkan oleh karyawan dan perusahaan agar mereka bias bekerja sama secara efektif.

Gaya Kepemimpinan yang efektif dibutuhkan pemimpin untuk dapat meningkatkan kinerja semua pegawai dalam mencapai tujuan organisasi.
Demikian Gaya Kepemimpinan dapat menjadi pedoman yang baik dalam peningkatan kinerja karyawan.

Berdasarkan latar belakang tersebut, maka penulis tertarik untuk melakukan penelitian mengenai "Pengaruh Gaya Kepemimpinan Terhadap Motivasi Kerja Karyawan Pada PT. Matahari Department Store di Manado".

\section{Kepemimpinan}

Berikut pengertian Gaya

Kepemimpinan menurut para ahli yaitu:

Menurut Robbins \& Coulter (2012:432), menyatakan bahwa :

"Proses pengaruh sosial, yaitu suatu kehidupan yang mempengaruhi kehidupan lain yang mempengaruhi orang lain kearah pencapaian tujuan tertentu".

George R. Terry

(2012:5) mengartikan bahwa Gaya Kepemimpinan adalah "Aktivitas untuk mempengaruhi orang-orang supaya diarahkan mencapai tujuan organisasi. Gaya Kepemimpinan meliputi proses mempengaruhi dalam menentukan tujuan organisasi, memotivasi perilaku pengikut untuk mencapai tujuan, mempengaruhi untuk memperbaiki kelompok dan budayanya”.

\section{Motivasi Kerja}

Dalam melakukan suatu pekerjaan setiap karyawan membutuhkan motivasi yang ada pada dirinya agar timbul suatu semangat atau kegairahan dalam bekerja. Motivasi berasal dari kata latin, yakni movere, yang berarti dorongan atau menggerakkan. 
Menurt Sondang P. Siagian (2004).

Teori motivasi pada dasarnya dibedakan menjadi dua teori kepuasan (content theory) dan teori proses (process theory).

Menurut Edwin B. Flippo yang dikutip oleh Hasibuan (2000) mendefisikan motivasi adalah sebagai suatu keahlian, dalam mengarahkan pegawai dan organisasi agar mau bekerja secara berhasil, sehingga keinginan para pegawai dan tujuam organisasi sekaligu tercapai. Sedangkan menurut Merle J. Moskowits mengemukan bahwa Motivasi didefinisikan sebagai inisiani dan pengarahan tingkah laku dan pelajaran motivasi sebenarnya merupakan pelajaran tingkah laku. Dari uraian di atas dapat disimpulkan bahwa motivasi sangat penting bagi perusahaan-perusahaan bukan saja mengharapkan karyawan mampu, cakap dan terampil tetapi yang terpenting mereka mau bekerja giat dan berkeinginan untuk mencapai hasil kerja yang maksimal. Kemapuan dan kecapan karyawan tidak ada artinya bagi perusahaan jika mereka tidak mau bekerja giat.

\section{Metode Penelitian}

Jenis penelitian yang digunakan dalam penelitian ini adalah jenis penelitian asosiatif. Menurut Sugiyono (2016: 80) penelitian asosiatif adalah penelitian yang bertujuan untuk melihat hubungan ataupun pengaruh antar variabel dalam penelitian yang dilakukan oleh peneliti. Penelitian ini akan mengambil PT. Matahari Department Store Area Megamall Manado sebagai objek penelitian dengan waktu penelitian diperkirakan selama 6 bulan terhitung mulai dari bulan Januari sampai dengan bulan Juni.

\section{Teknik Analisis Data}

\section{a. Uji Validitas}

Uji validitas digunakan untuk mengukur sah atau valid tidaknya suatu kuesioner. Suatu kuesioner dikatakan valid jika pertanyaan pada kuesioner mampu untuk mengungkapkan sesuatu yang diukur.

\section{b. Uji Reliabilitas}

Reliabilitas adalah istilah yang dipakai untuk menunjukkan sejauh mana suatu hasil pengukuran relatif konsisten apabila pengukuran diulangi dua kali atau lebih (Azwar, 1999 dalam Wibowo, (2012: 52). Metode reliabilitas yang sering digunakan dalam penelitian yaitu Cronbach's Alpha

\section{Uji Asumsi Klasik}

\section{a. Uji Normalitas}

Uji Normalitas dilakukan untuk mengetahui apakah sebuah model regresi, variabel independen, variabel dipenden, atau keduanya mempunyai distribusi normal atau tidak. Uji normalitas dapat dilakukan dengan melihat grafik histogram dan grafik Normal p - plot SPSS

\section{b. Uji Multikolinearitas}

Didalam persamaan regresi tidak boleh terjadi multikoliearitas, maksudnya tidak boleh ada korelasi atau hubungan yang sempurah atau mendekati sempurna antara variabel bebas yang membentuk persamaan tersebut. Gejala multikoliearitas 
dapat diuji dengan Variance Inflation Factor (FIV), pada tabel Coefficients.

\section{c. Uji Heteroskedastisitas}

Algifari (2000) dalam Wibowo (2012: 88) mengatakan suatu model dikatakan memiliki problem heteroskedastisitas itu berarti ada atau terdapat varian variabel dalam model yang tidak sama. Uji Heteroskedastisitas digunakan untuk menguji apakah dalam sebuah model regresi terjadi ketidaksamaan varians dari residual.

\section{Regresi Linier Berganda}

Analisis Regresi Linier Berganda pada dasarnya merupakan analisis yang memiliki pola teknis dan substansi yang hamper sama dengan regresi linier sederhana. Wibowo (2012: 126) mengatakan bahwa Model Regresi Linier Berganda dengan sendirinya menyatakan suatu bentuk hubungan linier antara dua atau lebih variabel independen dengan variabel dependennya.

\section{Hasil Penelitian}

\section{a. Uji Validitas}

Berdasarkan Tabel Uji Validitas maka diperoleh hasil, yaitu seluruh pernyataan baik itu pada Variabel Independent maupun Dependent dinyatakan Valid. Dapat dikatakan Valid karena seluruh pernyataan Variabel menghasilkan tingkat Koefisien lebih besar dengan tingkat signifikansi lebih kecil dari Alpha.

\section{b. Uji Reliabilitas}

\begin{tabular}{llll}
\hline $\begin{array}{l}\text { Nama } \\
\text { Variabel }\end{array}$ & $\begin{array}{l}\text { Koefisien } \\
\text { Alpha }\end{array}$ & Ket \\
\hline $\mathbf{X}$ & $\mathbf{0 , 7 4 0}$ & \multicolumn{2}{c}{ Rel } \\
\hline Y & $\mathbf{0 , 7 5 0}$ & Rel & \\
\hline \multicolumn{2}{c}{ Berdasarkan hasil } & dari & Uji
\end{tabular}

Reliabilitas bahwa semua pernyataan pada kuisioner dinilai reliabel karena nilai Cronbach's Alpha setiap variable lebih besar dari 0,6.

\section{c. Analisis Regresi Sederhana}

Berdasarkan tabel diatas, maka persamaan regresi linear berganda dengan 2 variabel independen sebagai berikut: $\mathbf{Y}=$ 25,521 + 0,607 Gaya Kepemimpinan+e. Persamaan regresi tersebut dapat dijelaskan sebagai berikut:

1. Konstanta sebesar 25,521 artinya jika Gaya Kepemimpinan (X1) bernilai Nol, maka nilai variabel dependen Motivasi Kerja Karyawan adalah sebesar 25,521.

2. Nilai koefisien Gaya Kepemimpinan (X1) sebesar 0,607, artinya jika variabel independen lain nilainya tetap dan Gaya Kepemimpinan (X1) mengalami kenaikan 1 point atau $1 \%$, maka Motivasi Kerja (Y) akan mengalami kenaikan sebesar 0,607 per 1 point/ 1 $\%$. Koefisien bernilai positif artinya terjadi hubungan positif antara X1 dan $\mathrm{Y}$, semakin naik $\mathrm{X} 1$ maka $\mathrm{Y}$ akan semakin naik. Berdasarkan tabel 4.9. diatas, dapat ditarik kesimpulan bahwa, dari tabel telihat bahwa nilai koefisien regresi Gaya Kepemimpinan memiliki tingkat sigifikansi 0,013 , nilai ini lebih kecil dari 0,05 atau nilai $\operatorname{sig}<\alpha$, ini 
berarti hipotesis penelitian yang menyatakan "Gaya Kepemimpinan berpengaruh terhadap Motivasi Kerja Karyawan "diterima.

Selain menggunakan nilai probabilitas atau nilai sig, metode yang lain yang dapat digunakan adalah dengan menggunakan nilai t hitung dibandingkan dengan nilai $\mathrm{t}$ tabel. Dalam kasus ini, $\mathrm{t}$ hitung memiliki nilai 2,581 sedangkan $\mathrm{t}$ table 2,017, ini berarti $\mathrm{t}$ hitung > t tabel sehingga hipotesis 2 dalam penelitian diterima. Kesimpulannya adalah bahwa variabel Gaya Kepemimpinan secara parsial tidak berpengaruh terhadap Motivasi Kerja Karyawan.

\section{d. Uji Koefisien Determinasi}

Diketahui bahwa nilai $R^{2}$ sebesar 0,137 atau $13,7 \%$. Hal ini menunjukkan bahwa variabel dependen Motivasi Kerja (Y) dapat dijelaskan oleh variabel independen yaitu variabel Gaya Kepemimpinan $\left(\mathrm{X}_{1}\right)$, sedangkan sisanya $86.3 \%$ dapat dipengaruhi atau dijelaskan oleh faktor lain diluar variabel atau variabel lain yang tidak di teliti dalam penelitian ini.

\section{Pembahasan}

\section{Pengaruh Gaya Kepemimpinan} terhadap Motivasi Kerja Karyawan (H1). Berdasarkan hasil uji hipotesis, diketahui nilai $\mathrm{t}$ hitung sebesar 2,581 dengan probabilitas signifikansi sebesar 2,017. Terlihat bahwa nilai probabilitas tersebut lebih besar dari 0,05 atau Sig > 0,05 dan hasil menunjukkan bahwa variabel Gaya Kepemimpinan $\left(\mathrm{X}_{1}\right)$ secara parsial berpengaruh positif dan signifikan terhadap Motivasi Kerja (Y). Ini berarti Hipotesis $1\left(\mathrm{H}_{1}\right)$ yang menyatakan bahwa "Gaya Kepemimpinan diduga berpengaruh terhadap Motivasi Kerja (Y)" terbukti atau diterima.

\section{Kesimpulan}

Berdasarkan hasil uji hipotesis (uji t) pada bab 4, dapat ditarik kesimpulan bahwa, dari tabel terlihat bahwa nilai koefisien regresi Gaya Kepemimpinan memiliki tingkat sigifikansi 0,013 , nilai ini lebih kecil dari 0,05 atau nilai sig $<\alpha$, ini berarti hipotesis penelitian yang menyatakan " Gaya Kepemimpinan berpengaruh terhadap Motivasi Kerja Karyawan” diterima. Selain menggunakan nilai probabilitas atau nilai sig, metode yang lain yang dapat digunakan adalah dengan menggunakan nilai $\mathrm{t}$ hitung dibandingkan dengan nilai $\mathrm{t}$ tabel. Dalam kasus ini, t hitung memiliki nilai 2,581 sedangkan t table 2,017, ini berarti $\mathrm{t}$ hitung $>\mathrm{t}$ tabel sehingga hipotesis 2 dalam penelitian diterima. Kesimpulannya adalah bahwa variabel Gaya Kepemimpinan secara parsial tidak berpengaruh terhadap Motivasi Kerja Karyawan.

\section{Saran}

Berdasarkan kesimpulan, maka saran yang dapat diberikan yang pertama, oleh karena Gaya Kepemimpinan berdampak langsung bagi Motivasi Kerja Karyawan, maka pihak Matahari harus 
memperhatikan Gaya Kepemimpinan yang ada. Hasil menunjukkan bahwa Gaya Kepemimpinan di Matahari Mega Mall di Manado berpengaruh positif dan signifikan. Ini berarti bahwa Gaya Kepemimpinan di Matahari Mega Mall sudah baik dan harus ditingkatkan. Berpengaruh positif disini artinya, semakin Gaya Kepemimpinan ditingkatkan oleh pihak Matahari Mega Mall maka semakin meningkat pula Motivasi Kerja Karyawan untuk bekerja untuk berbelanja di Matahari Mega Mall di Manado.

\section{Daftar Pustaka}

Robbins, S. P. Dan Mary. C. (2012). Manajemen, Jilid 2, Edisi Kesepuluh, Alih Bahasa: Bob Sabran dan Devri Bernadi Putera. Erlangga. Jakarta.

Hasibuan , M. (2000). Organisasi dan Motivasi Dasar peningkatan Produktifitas.Jakarta: PT. Bumi Askara

Wibowo, E. (2012). Aplikasi Praktis Spss Dalam Penelitian. Yogyakarta: Gava Media

Terry G.R. (2012). Manajemen Sumber Daya Manusia. Alih bahasa oleh Sadili Samsudin. Cetakan ke-6. Jakarta. PT Raja Grafindo.

Siagian, S. (2004). Manajemen Sumber Daya Manusia. Jakarta: PT. BumiAksara.

Sugiyono. (2016). Metode Penelitian Kuantitatif, Kualitatif, dan $R \& D$. Bandung: Alvabeta. 